\title{
ARTIKELEN
}

\section{Raphael Lemkin en de misdaad zonder naam}

\author{
Reyer Baas
}

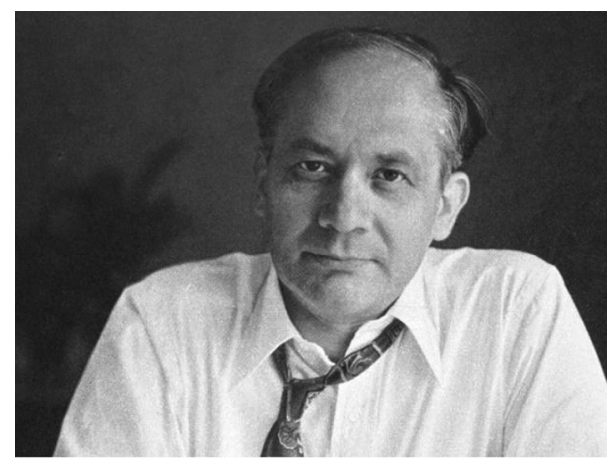

Raphael Lemkin

\section{$1 \quad$ Inleiding}

In 1921 vond in Berlijn een geruchtmakend strafproces plaats tegen een Armeniër die terechtstond voor de moord op een Turkse oud-minister. Een paar maanden eerder had Soghomon Tehlirian inderdaad op klaarlichte dag Talaat Pasja neergeschoten onder het uitroepen: 'Dit is om de moord op mijn familie te wreken!' Talaat Pasja was een van de architecten van de massamoord op de Armeniërs tijdens de Eerste Wereldoorlog. Om aan gevangenschap door de geallieerden te ontkomen, was hij aan het einde van de oorlog naar Duitsland gevlucht. Daar leidde hij een rustig bestaan, gevrijwaard van strafvervolging. Voor Tehlirian, die de moordpartij op zijn familie als enige wonderwel had overleefd, was deze gedachte onverdraaglijk.

Achthonderd kilometer oostwaarts las een Poolse student met de naam Raphael Lemkin over het proces in een lokale krant. Tot zijn ontsteltenis constateerde Lemkin dat Tehlirian wél berecht kon worden voor de moord op één persoon, terwijl het slachtoffer - verantwoordelijk voor de dood van meer dan één miljoen mensen - nooit terecht had kunnen staan onder het internationaal recht van die tijd. Staatssoevereiniteit belemmerde immers bestraffing. Toen Lemkin de zaak onder de aandacht bracht van een van zijn docenten, was diens reactie: 'Vergelijk het met een boer die een kippenfarm drijft. Als de boer besluit zijn kippen de nek om te draaien, dan is dat zijn zaak. Als je je daarmee bemoeit, ben je in overtreding.' ${ }^{1}$ 
Het incident had grote impact op Lemkins gedachtevorming. Bij hem groeide de overtuiging dat staatsmisdrijven door middel van internationaal recht moesten worden beteugeld. Uiteindelijk zou hij zijn levenswerk maken van de universele bestraffing van volkerenmoord - een misdrijf dat tot dusver niet in de wetboeken voorkwam en waar zelfs nog geen naam voor bestond. Pas in 1948 werd genocide tot een internationaal misdrijf verklaard. Dat dit gebeurde, is voor een aanzienlijk deel op Lemkins conto te schrijven.

In deze bijdrage onderzoek ik Lemkins streven naar erkenning, preventie en bestraffing van genocide, in welke zin hij voor de totstandkoming hiervan beslissend was en welke betekenis zijn werk heeft gehad op de lange termijn.

\section{Vroege jaren}

Raphael Lemkin werd in 1900 geboren in een gehucht ten oosten van Bialystok in een ontwikkeld joods boerengezin. Destijds maakte zijn geboortestreek deel uit van het Russische tsarenrijk, tegenwoordig ligt het in het westen van Wit-Rusland. Het gebied was multi-etnisch en -religieus door de talrijke grenscorrecties en volksverhuizingen die de afgelopen eeuwen hadden plaatsgevonden. Over Lemkins vroege jaren is weinig bekend. Raphael en zijn twee broers kregen een religieuze opvoeding, maar het gezin was niet strenggelovig. Met name zijn moeder was zeer belezen. Ze schilderde, studeerde en onderwees haar zoons thuis in talen. Ook Raphael bleek een talenwonder: op vroege leeftijd zou hij al Pools, Russisch, Oekraïens, Hebreeuws, Jiddisch en Duits hebben gesproken. Hij verslond het ene boek na het andere en leerde zo over de lotgevallen van de vroege christenen in Rome, de plunderingen door de Mongoolse horden en de verdrijving van de Franse hugenoten. Later beschreef Lemkin hoe geschokt hij was toen hij las dat christenen onder Nero in de arena aan de leeuwen werden gevoerd. Hij vroeg zijn moeder waarom die dan de politie er niet bij haalden. Maar hoe had die dan moeten helpen, was de wedervraag: keizer Nero zat zelf in het publiek.

Lemkin en zijn familie ervoeren aan den lijve hoe kwetsbaar minderheidsgroepen kunnen zijn. In de nadagen van het Russische tsarenrijk was antisemitisme wijdverspreid en kwamen bij tijd en wijle pogroms voor. De overheid liet die niet alleen toe, maar stimuleerde ze ook heimelijk om de aandacht af te leiden van binnenlandse problemen. Het geweld van de Eerste Wereldoorlog bracht eveneens misère voor de familie Lemkin. Tweemaal werd hun boerderij verwoest, hun oogst werd in beslag genomen en een van Lemkins broers overleed aan longontsteking. Niettemin kon Lemkin zijn gymnasium voltooien en wist de familie zelfs een studie voor hem te bekostigen. In 1920 begon hij als student taalwetenschap aan de Jan Kazimierz Universiteit te Lviv, in het herrezen Polen. Kort daarop, toen berichten doorsijpelden over de massamoord op de Armeniërs, besloot hij over te stappen naar rechten, waarin hij in 1926 promoveerde. De jaren daarna werkte Lemkin als griffier van het gerechtshof en later als openbaar aanklager in Warschau. Tot 1939 was hij daar tevens wetenschappelijk medewerker aan de Vrije Poolse Universiteit. In die hoedanigheid werkte hij mee aan de codificatie van het Poolse strafrecht. Ook legde hij zich toe op de vertaling van diverse Europese wet- 
Reyer Baas

boeken van strafrecht, waaronder die van Italië en de Sovjet-Unie. Lemkin constateerde dat er in de fascistische en communistische rechtssystemen opvallende parallellen te vinden waren. Zo heerste de groep over het individu, heerste de ene groep over de andere, en heerste de staat over iedereen. Individuele belangen waren vaag gedefinieerd om 'sociale belangen' te beschermen. Het recht van Italië en de Sovjet-Unie legitimeerde de staat om burgers ongestraft kwaad te doen. Lemkin las dergelijke bepalingen als een voorbode van allerlei van staatswege georganiseerd onheil. Hij was vastbesloten met dezelfde instrumenten - het recht - te proberen om het tegendeel te bereiken: het voorkomen en bestraffen van misdaden van staten tegen hun eigen volk. ${ }^{2}$

\section{Ontwikkeling van het concept genocide}

In 1933 werd in Madrid een conferentie gehouden over internationaal strafrecht, dat in die dagen nog in de kinderschoenen stond. Lemkin nam deel aan de conferentie als lid van de Poolse delegatie. Hij hield er een vlammend betoog om de verzamelde landen te bewegen 'de vernietiging van nationale, religieuze en raciale groepen' tot internationaal misdrijf te verklaren, net als was gebeurd met slavernij, piraterij en drugssmokkel. ${ }^{3}$ Lemkin onderscheidde twee varianten van dit misdrijf: het kon gaan om de vernietiging van het cultuurgoed van een minderheid, welke praktijk Lemkin vandalisme doopte, maar ook om de uitroeiing of onderdrukking van minderheden zelf, wat hij barbarij noemde. ${ }^{4}$ De delegaties hadden echter weinig belangstelling en Lemkins voorstel werd niet eens in stemming gebracht. Volgens Lemkin meenden de gedelegeerden dat volkerenmoord zo sporadisch voorkwam dat het onnodig was er wetgeving aan te wijden, ${ }^{5}$ hoewel deze opvatting datzelfde jaar nog was gelogenstraft door de massamoord op Assyriërs in Irak. De machtsovername van Hitler in Duitsland beloofde weinig goeds. Deze maakte echter geen indruk. De Poolse regering wenste Lemkin bovendien vanwege diens joodse wortels niet prominent te laten figureren op de conferentie. In die dagen zocht Polen toenadering tot nazi-Duitsland om zich te wapenen tegen het Sovjetgevaar dat in het oosten opdoemde. Kort hierna werd Lemkin uit zijn publieke functies ontheven. Daarop begon hij een praktijk als advocaat en legde zich toe op het fiscaal en handelsrecht. ${ }^{6}$

In 1939 viel Duitsland Polen binnen. Lemkin, als jood en intellectueel in acuut gevaar, verschool zich met een groep vluchtelingen maandenlang in de Poolse bossen. In november vond hij onderdak bij een joodse familie, die tot zijn verbijstering haar naderende lot gelaten aanvaardde. Lemkin nam de trein verder oost-

2 De biografische gegevens in deze paragraaf zijn afkomstig uit: Vrdoljak 2009, p. 1166-1168, p. 1175-1176; Cooper 2008, p. 11, p. 15-17; Power 2007, p. 20-21; Elder 2005, p. 470-471, p. 473.

3 Lemkin 1933.

4 Lemkin 1944, p. 91. Het laatste concept was recent ontwikkeld door de Roemeense jurist Vespasian Pella.

5 Schabas 2009, p. 30.

$6 \quad$ Elder 2005, p. 471, p. 475. 
waarts, waar hij verenigd werd met zijn familie. Ook zijn bejaarde ouders waren niet gevoelig voor zijn smeekbeden om met hem het onheil te ontvluchten. In 1940 wist hij via Litouwen naar Zweden te ontsnappen. Een jaar lang doceerde Lemkin internationale financiën aan de universiteit van Stockholm. Intussen verzamelde hij zo veel mogelijk regelgeving die de Duitsers in de bezette gebieden hadden uitgevaardigd. Malcolm McDermott, een rechtenhoogleraar aan Duke University (VS) met wie Lemkin in de jaren dertig had samengewerkt, nodigde hem uit om aan zijn universiteit docent te worden. Met alle verzamelde nazidecreten in zijn bagage begon Lemkin aan de reis oostwaarts, die hem dwars door Siberië naar Japan voerde. In de lente van 1941 bereikte hij Amerika. ${ }^{7}$

Dankzij zijn kennis van internationale politiek en handel kon Lemkin gaan werken als adviseur van de regering inzake buitenlands beleid en economische oorlogsvoering. ${ }^{8}$ In deze functie had hij toegang tot politici en beleidsmakers, die hij probeerde te overtuigen van de gruwelen die in Europa plaatsvonden en van de noodzaak tot ingrijpen. In 1944 publiceerde hij het 674 pagina's tellend boek Axis rule in occupied Europe, waarin hij de praktijk en regelgeving van de Europese asmogendheden analyseerde als gecoördineerde handelingen gericht op de vernietiging van specifieke groepen mensen. ${ }^{9}$ Het boek bestaat uit drie delen. Het eerste daarvan behandelt de werkwijzen van voornamelijk Duitsland en Italië op het gebied van bestuur, politie, recht en rechtspraak, eigendom, financiën en arbeid. Ook aan de juridische status van de joden en het concept genocide zijn hoofdstukken gewijd. In het tweede deel geeft Lemkin een analyse van het bewind in de bezette landen. Het laatste en meest omvangrijke deel bevat een selectie van de wetten en decreten die de bezetters hadden uitgevaardigd. Het boek is vooral bekend geworden doordat Lemkin er het begrip genocide in lanceerde. In een radiotoespraak in augustus 1941 had de Britse premier Winston Churchill zich uitgesproken tegen de 'methodical, merciless butchery on such a scale', die de nazi's in de bezette gebieden in het oosten bedreven. En hij vervolgde: 'We are in the presence of a crime without a name.' Enkele jaren later vulde Lemkin deze leemte door het begrip genocide te creëren. Hij stelde dit samen uit het Griekse woord genos, dat ras of volk betekent, en het Latijnse suffix -cide, dat refereert aan moord. Oudere termen als barbarij en vandalisme achtte hij bij nader inzien niet geschikt, omdat die de ware aard en ernst van genocide niet blootleggen: 'New conceptions require new terms. ${ }^{10}$ Lemkin onderscheidde genocide van andere ernstige mensenrechtenschendingen door de nadruk te leggen op de specifieke intentie om een bepaalde groep mensen te vernietigen; niet in hun individuele hoedanigheid, maar als leden van de groep. 
Reyer Baas

\section{De Genocideconventie}

Onzekerheid over het lot van zijn familie tijdens de oorlog bracht Lemkin in een zware depressie. Na de oorlog werd zijn vrees bewaarheid: bijna zijn hele familie in Europa was omgekomen. Zijn broer had als een van de weinigen weten te overleven. De tragedie sterkte Lemkin in zijn welhaast obsessieve drang om de internationale strafbaarstelling van genocide te verwezenlijken. ${ }^{11}$ In $1945 \mathrm{kreeg}$ hij een aanstelling bij het Internationale Militaire Tribunaal van Neurenberg als adviseur van aanklager Robert Jackson. Lemkin deed verwoede pogingen om het woord genocide te introduceren in de rechtspraak van het tribunaal, maar zonder resultaat. Britse aanklagers wierpen tegen dat het woord niet in de Oxford English Dictionary stond. In geen van de vonnissen die het tribunaal in oktober 1946 uitsprak, werd aan genocide gerefereerd. Men sprak van misdrijven tegen de menselijkheid, dat blijkens de omschrijving van de aanklager het begrip genocide grotendeels omsloot. Dit kon evenwel niet op Lemkins goedkeuring rekenen, omdat vervolging voor deze misdaden door het Neurenberg Tribunaal alleen mogelijk was als ze in oorlogstijd waren gepleegd. Geen van de nazi's kon in Neurenberg worden veroordeeld voor misdrijven die vóór september 1939 waren begaan. ${ }^{12}$ Op deze manier zouden staten vrijuit kunnen gaan door in vredestijd genocide te plegen of toe te staan. ${ }^{13}$ Robert Jackson motiveerde de jurisdictie van het Neurenberg Tribunaal om nazi's te vervolgen voor misdrijven tegen de menselijkheid als volgt:

'[T]he way Germany treats its inhabitants is not our affair. The reason that this program of extermination of Jews becomes an international concern is that it was a part of a plan for making war. Unless we have a war connection as a basis for reaching them, I would think we have no basis for dealing with atrocities. $^{14}$

Gefrustreerd toog Lemkin naar New York om de Algemene Vergadering van de onlangs opgerichte Verenigde Naties ervan te overtuigen genocide als een internationaal misdrijf te bestempelen. Lemkin had gezelschap van een groot aantal lobbyisten die de jonge volkerenorganisatie overstelpten met plannen en wensen, maar hij wist zich te onderscheiden als degene die al ver vóór de oorlog als een Cassandra had gewaarschuwd voor de dreiging uit het oosten en de noodlottige gevolgen als de wereldgemeenschap passief zou blijven. Lemkin bestookte politici,

11 Cooper 2008, p. 46, p. 52; Power 2007, p. 49-50.

12 Lemkin 1947, p. 147-148.

13 In 1999 oordeelde het Joegoslavië-tribunaal dat misdrijven tegen de menselijkheid naar internationaal gewoonterecht ook in vredestijd kunnen worden gepleegd (Prosecutor v. Dusko Tadić (Case it-94-1-A), Judgment ICTY (ac), 15 juli 1999, par. 251); bevestigd in o.a.: Prosecutor v. Fatmir Limaj (Case it-03-66T), Judgment ICTY (tc), 30 november 2005, par. 180). In het Statuut van Rome van 1998 (in werking getreden in 2002), waarmee het Internationaal Strafhof is opgericht, wordt geen onderscheid gemaakt tussen misdrijven tegen de menselijkheid begaan ten tijde van oorlog of vrede. Zie ook Wald 2007.

Schabas 2009, p. 40. 
diplomaten, journalisten en andere spraakmakende figuren met brieven en publicaties om hen voor zijn zaak te winnen. Maandenlang zwierf hij rond in de duistere gangen van de voormalige fabriek op Long Island, waar de VN toen nog gehuisvest waren - gedelegeerden, ambtenaren, voorlichters en journalisten aanklampend. 'Here's that pest, that Lemkin. I have a genocide story for you', sprak hij bij een van die gelegenheden verontschuldigend tegen de aanwezige pers. Lemkin was een solist zonder middelen of organisatie. Hij bekleedde geen positie binnen de VN, was diplomaat noch politicus en had zelfs geen kantoor of medewerkers. Maar de bewaking liet hem telkens weer binnen: 'What, Lemkin, you here again?'15

In zijn campagne om genocide strafbaar te stellen wierp Lemkin niet alleen morele argumenten op, maar hij wees ook op praktische belangen. Zo schreef hij dat de verdrijving van ongewenste burgers tot spanningen met buurlanden leidt, die hen moeten opvangen. Ook lijdt de handel schade als mensen zomaar van hun bezittingen kunnen worden beroofd. Als zij niets meer hebben, kunnen schuldeisers ook niets meer op hen verhalen. Genocide brengt bovendien internationale spanningen teweeg die kunnen resulteren in oorlog. En niet in de laatste plaats berokkent volkerenmoord het cultureel werelderfgoed immense schade:

'Our whole heritage is a product of the contributions of all nations. We can best understand this when we realize how impoverished our culture would be if the peoples doomed by Germany, such as the Jews, had not been permitted to create the Bible, or to give birth to an Einstein, a Spinoza; if the Poles had not had the opportunity to give to the world a Copernicus, a Chopin, a Curie; the Czechs, a Huss, a Dvorak; the Greeks, a Plato and a Socrates; the Russians, a Tolstoy and a Shostakovich. ${ }^{16}$

Lemkins inspanningen bleken niet vruchteloos. Hij had vernomen dat de LatijnsAmerikaanse delegaties welwillend tegenover zijn plannen stonden. Dat was goed nieuws, aangezien de Latijns-Amerikaanse landen destijds zo'n veertig procent van de Verenigde Naties uitmaakten. Lemkin probeerde eerst kleine landen binnen te halen, waarna de grote gemakkelijker zouden volgen. ${ }^{17} \mathrm{Hij}$ zocht contact met Ricardo Alfaro, de Panamese delegatieleider bij de VN. Lemkin overhandigde Alfaro publicaties over het belang van genocidebestrijding, waaronder zijn boek Axis rule. De jurist Alfaro was geïnteresseerd en vroeg 24 uur tijd om het materiaal te bestuderen. De dag erna tekende hij de resolutie. Ook Cuba bleek ontvankelijk voor Lemkins pleidooi. Er was nu nog één staat te gaan, want met de handtekening van drie landen was het mogelijk in de Algemene Vergadering een resolutievoorstel in te dienen. De gewenste derde handtekening kreeg Lemkin van India.

17 Van Lemkins tactiek werd ook in de Nederlandse krant Het Vrije Volk gewag gemaakt. Zie: J.W.F. Stoppelman, 'Wet tegen groepenmoord van ideaal tot een feit. Conventie verbiedt alle landen onmenselijkheid', Het Vrije Volk 28 oktober 1950, p. 1-2. 
Reyer Baas

Een godsgeschenk, want in het kielzog van dit grote Aziatische land zouden andere staten spoedig kunnen volgen. ${ }^{18}$

Toen genocide eenmaal op de agenda van de Algemene Vergadering stond, was het zaak zo veel mogelijk staten over te halen de resolutie te steunen. Lemkins meeste lobbywerk ging zitten in het bewerken van de Amerikaanse media. Als die de Amerikaanse publieke opinie en politiek konden bewegen zich sterk te maken voor de genocideresolutie, dan was een belangrijke slag gewonnen. De Amerikaanse delegatie bij de VN bleek inderdaad geporteerd voor Lemkins voorstel en kondigde aan de resolutie te steunen. Ook de Fransen en Britten kreeg Lemkin mee, maar de Sovjets toonden aanvankelijk geen enkel enthousiasme om de genocideresolutie te omarmen. Gedeeltelijk was Sovjet-delegatieleider Vysjinski hiervoor verantwoordelijk. Die had in de jaren dertig Lemkins ideeën afgedaan als contrarevolutionaire pogingen van het westen om zich met interne aangelegenheden van de Sovjet-Unie te bemoeien. Belangrijker nog was dat de Sovjets vreesden last te kunnen krijgen van internationaal genociderecht, aangezien zij zelf tijdens de oorlog massaal volkeren hadden gedeporteerd die ze verdachten van samenwerking met de Duitsers. Lemkin overreedde de Tsjecho-Slowaakse minister van Buitenlandse Zaken, Masaryk, om met Vysjinski te gaan praten. Wat hebben de Russen te vrezen van het recht, vroeg Lemkin volgens de overlevering aan Masaryk: de uitvinding van de penicilline was toch ook geen samenzwering tegen de Sovjet-Unie geweest? Masaryk schreef in zijn agenda: 'Vysjinsky. Genocide. Penicilline.' Daags erna belde hij Lemkin op: de Russen waren binnen. ${ }^{19}$

De resolutie werd op 11 december 1946 unaniem aangenomen. ${ }^{20}$ Ze bevestigde dat genocide een misdrijf onder internationaal recht was, riep staten op nationale wetgeving aan te nemen waarin volkerenmoord werd bestraft, en ze beval internationale samenwerking aan om haar te voorkomen en bestraffen. Bovendien kreeg de Economische en Sociale Raad van de VN de opdracht om een ontwerpverdrag te schrijven. Dit was de grootste winst, want een resolutie is weliswaar van normatieve waarde, maar met de strafbaarstelling van genocide bij verdrag zou er pas werkelijk sprake zijn van bindend recht. De commissie die met het ontwerpen van de conventie werd belast, bestond uit de rechtsgeleerden Vespasian Pella, Henri Donnedieu de Vabres (voorheen rechter in het Neurenberg Tribunaal) en Raphael Lemkin zelf.

Tijdens de onderhandelingen over de totstandkoming van het verdrag bleek dat met name definitiekwesties de partijen verdeeld hielden. Die betroffen hoofdzakelijk de vraag wat als daad van genocide moest worden aangemerkt en welke groepen mensen bescherming van het verdrag dienden te krijgen. Lemkin had graag gezien dat ook culturele genocide, voorheen vandalisme genoemd, als een vorm van volkerenmoord werd erkend. Dit gebeurde niet. Het voorstel van Syrië om etnische zuivering als genocide te bestempelen, haalde het evenmin. Gelet op de aard van genocide is dit niet onbegrijpelijk: de verdrijving van mensen is niet

18 Voor een verslag van de aanloop naar het genocideverdrag en Lemkins lobby, zie onder meer Schabas 2009, p. 59-90; Cooper 2008, p. 76-110.

19 Cooper 2008, p. 80-86; Power 2007, p. 53-54.

20 UN General Assembly Resolution 96 (i), 11 december 1946. 
noodzakelijkerwijs gericht op hun vernietiging. ${ }^{21}$ Anders dan Lemkin wenste, ging voor genocide geen universele maar slechts territoriale jurisdictie gelden. Weliswaar stond in het ontwerpverdrag dat een (ooit op te richten) internationaal straftribunaal rechtsmacht zou kunnen krijgen, maar de onderhandelende staten wensten in meerderheid nationale gerechten niet bevoegd te verklaren om daders van genocide te berechten die buiten de grenzen van hun land was gepleegd. Voorstanders van universele jurisdictie stelden vergeefs dat bij gebreke hiervan genocideplegers hun straf zouden ontlopen: landen waarin genocide was gepleegd, zouden namelijk onwillig zijn om de daders daarvan te bestraffen. ${ }^{22}$ Pas met de oprichting van het Internationaal Strafhof in 1998 zou er een permanent internationaal straftribunaal komen.

Binnen de Algemene Vergadering bestond grote verdeeldheid over de vraag of ook andere groepen dan nationale, etnische, raciale en religieuze groepen bescherming van de Genocideconventie zouden moeten krijgen. Ook andere categorieën kunnen tenslotte blootstaan aan hevige vervolging. Binnen het driemanschap liepen de opvattingen hierover eveneens zeer uiteen. De grootste splijtzwam was opneming van politieke groepen. Lemkin meende dat deze het permanente karakter en de specifieke kenmerken missen van de andere groepen. Opneming ervan zou controversieel en onnodig zijn. Donnedieu de Vabres nam een rekkelijker positie in en vond dat volkerenmoord ongeacht welke groep het betrof een weerzinwekkend misdrijf was dat bij verdrag moest worden verboden. Pella meende dat de Algemene Vergadering hierover moest oordelen. Binnen dit gremium gaven de Verenigde Staten uiteindelijk de doorslag. Hoewel het land er voorstander van was om politieke groepen bescherming te bieden, besloot het toch tegen te stemmen om te voorkomen dat het enkele landen ervan zou weerhouden zich bij de conventie aan te sluiten. ${ }^{23}$ Lemkin kreeg dus zijn zin: politieke (en andere groepen) kwamen er niet in. Deze uitsluiting heeft ertoe geleid dat bijvoorbeeld de massamoord op koelakken in de Sovjet-Unie onder Stalin, op communisten in Indonesië onder Soeharto en op geschoolde mensen in Cambodja onder de Rode Khmer formeel niet als genocide worden beschouwd.

De dag waarvan Lemkin dacht dat hij nooit zou komen, kwam op 9 december 1948. Met algemene stemmen werd het ontwerp van de Genocideconventie in de Algemene Vergadering aangenomen. ${ }^{24}$ Verslaggevers verhaalden van het feit dat

21 De Algemene Vergadering van de VN verklaarde in een resolutie in 1992 etnische zuivering wel tot genocide, maar dit veranderde niets aan de verdragstekst. Diverse staten, waaronder Cambodja, Spanje en Roemenië, hebben in hun nationale wetgeving wel een ruimere definitie van genocide opgenomen.

22 Cooper 2008, p. 124-125.

23 Bechky 2012, p. 603, p. 609-610; Schabas 2009, p. 154, p. 159; Jones 2006, p. 14. Vooral de Sovjet-Unie en haar bondgenoten waren tegenstander van opneming van politieke groepen, mogelijk uit vrees dat de Genocideconventie dan van toepassing zou zijn op misdrijven van het Sovjetregime.

24 Daarmee is nog niet gezegd dat de leden van de Algemene Vergadering de conventie ook bekrachtigden (ratificeerden). Pas als dit gebeurd is, vaak na instemming van het parlement, wordt een staat partij bij een verdrag. 
Lemkin tijdens zijn finest hour spoorloos was. Zij troffen hem eenzaam en door emoties overmand aan in een verduisterde zijzaal. ${ }^{25}$

Wat zijn de verdragsluitende partijen in de Genocideconventie overeengekomen ${ }^{26}$ Allereerst stellen zij vast dat genocide, ongeacht of ze in vredes- dan wel in oorlogstijd wordt gepleegd, een misdrijf is krachtens internationaal recht, dat zij op zich nemen te voorkomen en te bestraffen (artikel I) ${ }^{27}$ Vervolgens wordt het begrip genocide gedefinieerd (artikel II). Daaronder wordt verstaan:

een van de volgende handelingen, gepleegd met de bedoeling om een nationale, etnische, godsdienstige of raciale groep geheel of gedeeltelijk als zodanig te vernietigen:

a. het doden van leden van de groep;

b. het toebrengen van ernstig lichamelijk of geestelijk letsel aan leden van de groep;

c. het opzettelijk aan de groep opleggen van levensvoorwaarden die gericht zijn op haar gehele of gedeeltelijke lichamelijke vernietiging;

d. het nemen van maatregelen, bedoeld om geboorten binnen de groep te voorkomen;

e. het gewelddadig overbrengen van kinderen van de groep naar een andere groep.

De conventie is redelijk uitgesproken over de verplichtingen inzake bestraffing. Zo bepaalt zij dat genocideplegers dienen te worden bestraft (artikelen III en IV) en draagt ze lidstaten op wetgeving aan te nemen waarmee de bepalingen van de conventie worden geëffectueerd (artikel V). Verdachten van genocide moeten krachtens artikel VI ofwel worden berecht voor een tribunaal in het land waar volkerenmoord heeft plaatsgevonden ofwel voor een bevoegd internationaal straftribunaal. ${ }^{28}$ De conventie bepaalt verder dat lidstaten zich ertoe verbinden genocide te voorkomen. Deze niet onproblematische verplichting wordt onder meer ingevuld door het weinig spectaculaire artikel VIII, waarin is bepaald dat elke lidstaat de bevoegde organen van de VN mag oproepen datgene te ondernemen wat deze organen geschikt achten om genocide te voorkomen en onderdrukken, over-

Rosenthal 1988.

Officieel heet de conventie: het Verdrag inzake de Voorkoming en de Bestraffing van Genocide.

Gelezen naar de letter van de conventie wordt het plegen van genocide er niet in verboden. Deze anomalie heeft geleid tot (een tamelijk onzinnige) discussie over de vraag of genocidale handelingen verdragsrechtelijk wel verboden zijn. Hieraan heeft het Internationaal Gerechtshof een einde gemaakt door in de zogeheten Genocidezaak te overwegen dat het doel van de conventie ook een verbod op het plegen van genocide impliceert. De conventie behelst dus niet alleen positieve, maar ook negatieve verplichtingen (Application of the Convention on the Prevention and Punishment of the Crime of Genocide (Bosnia and Herzegovina v. Serbia and Montenegro), Judgment, ICJ Reports, 26 februari 2007, par. 166, 162).

28 In geval van berechting door een internationaal tribunaal dienen de lidstaten verdachten te arresteren en over te leveren. De eerste internationale straftribunalen sinds de aanvaarding van de Genocideconventie (het Joegoslavië- en Rwandatribunaal) werden opgericht in de jaren negentig van de twintigste eeuw. 
eenkomstig het VN-Handvest. Meer betekenisvol is dat de conventie in artikel IX rechtsmacht voor het Internationaal Gerechtshof creëert om geschillen tussen staten te berechten over de interpretatie, toepassing of tenuitvoerlegging van het verdrag. ${ }^{29}$

De aanvaarding van de Genocideconventie deed Lemkins bekendheid bijzonder goed. Hij werd veelvuldig gevraagd voor interviews en schreef het ene artikel na het andere. Hij ontving tal van onderscheidingen en tweemaal werd hij genomineerd voor de Nobelprijs voor de Vrede. Lemkin gebruikte de aandacht om zo veel mogelijk landen ertoe te zetten zich bij de conventie aan te sluiten. Vooral ratificatie door de Verenigde Staten was belangrijk. Lemkin geloofde dat als de VS eenmaal over de streep was, andere landen dan vanzelf zouden volgen. Bekrachtiging door de VS zou evenwel nog tot 1988 op zich laten wachten vooral door onwil en traagheid van de Senaat, hoewel president Truman een groot pleitbezorger was van de Genocideconventie en senator William Proxmire negentien jaar lang elke zittingsdag een rede hield over de noodzaak tot ratificatie. ${ }^{30}$

Met Lemkins gezondheid ging het intussen bergafwaarts. Toen Lemkin met maagklachten in het ziekenhuis werd opgenomen, schreef hij in zijn dagboek: 'The strong feeling that my mission depended so much on this harassed body made my inner will issue orders to this body: do not cease to exist!' ${ }^{31}$ Zelf diagnosticeerde hij zijn chronische kwalen als 'genociditis: uitputting van het werken aan de Genocideconventie'. ${ }^{32}$

Het jaar 1951 bracht echter goed nieuws: het Internationaal Gerechtshof verklaarde het genocideverbod tot dwingend recht (zie paragraaf 5) en inmiddels hadden zich twintig staten bij de Genocideconventie aangesloten: voldoende om het verdrag in werking te laten treden. Lemkin was intussen gaan werken als docent strafrecht aan Yale University (1948). In 1955 werd hij hoogleraar internationaal recht aan Rutgers School of Law. De laatste jaren van zijn leven omschreef Lemkin in zijn autobiografie als 'verdediging, verspreiding, onderzoek en onderricht'. Met verdediging doelde hij op het werk om enerzijds nationale parlementen ertoe te zetten de Genocideconventie te ratificeren en anderzijds misinterpretatie ervan te bestrijden en aanvallen van conventie-criticasters af te slaan. Verspreiding zag op de verkondiging van de boodschap. Onderzoek hield voor Lemkin vooral het schrijven van een monografie over de geschiedenis van genocide in. ${ }^{33}$ Onderricht kwam neer op het onderwijzen van het publiek en van

29 In 1993 werd voor het eerst een procedure voor het Internationaal Gerechtshof op grond van artikel IX gestart (en voltooid), toen Bosnië-Herzegovina Joegoslavië daagde wegens schending van de Genocideconventie.

30 In de Senaat werd gevreesd dat de Genocideconventie de Amerikaanse soevereiniteit en de speelruimte in het buitenlands beleid zou inperken. Zie hierover: LeBlanc 1991; Power 2007, p. 65-70. Er dringt zich een parallel op met de oprichting van de Volkenbond in 1919: ook toen liep aansluiting van Amerika bij een internationaal instituut stuk op onwil van het Congres, ondanks bezielde pleidooien van president Wilson om wel lid te worden. Overigens was ook Nederland relatief laat met toetreding tot de Genocideconventie in 1966.

31 Jacobs \& Totten 2002, p. 398.

32 Elder 2005, p. 484.

33 Getiteld History of Genocide. 
Reyer Baas

juristen om hen ervan te doordringen hoe belangrijk het was dat er een einde kwam aan genocide - was het niet door het geweten, dan wel door het recht. Ook begon Lemkin aan zijn autobiografie, opdat zijn leven als voorbeeld voor anderen zou kunnen dienen. ${ }^{34}$ Want met de aanvaarding van de conventie was een belangrijk doel bereikt, maar er was, vond hijzelf, nog een lange weg te gaan. ${ }^{35}$

\section{Lemkin als factor}

Lemkin kan als schoolvoorbeeld gelden van wat een norm entrepreneur wordt genoemd: een individu of organisatie die ernaar streeft gedragsverandering teweeg te brengen. ${ }^{36}$ Lemkin heeft hieraan voldaan met zijn campagne om mensen bewust te maken van de noodzaak om genocide te bestrijden. Dit deed hij eerst door het begrip genocide te introduceren en te duiden, daarna door met een grootschalige lobby van de voorkoming en bestraffing van genocide een norm te maken en ten slotte door te werken aan de schepping van een genocideverdrag. Lemkin wees in zijn lobby niet alleen op het belang van genocidebestrijding zelf, maar ook op de ongerijmdheid om volkerenmoord niet internationaal strafbaar te stellen, maar vergelijkbare wandaden, zoals slavernij, wel. Deze methode van norm grafting - het promoten van een niet-aanvaarde norm door te wijzen op vergelijkbare maar wel aanvaarde normen - heeft Lemkin consequent toegepast. ${ }^{37}$ Zodra de Genocideconventie was gesloten ondernam Lemkin een campagne om zo veel mogelijk staten ertoe te bewegen haar te ondertekenen. 'Never in the history of the United Nations has one private individual conducted such a lobby', schreef John Humphrey, auteur van de Universele verklaring van de rechten van de mens. ${ }^{38}$ Toch springt één omissie in Lemkins campagne in het oog. Norm entrepreneurs scheppen in de regel ook principled-issue networks. ${ }^{39}$ Lemkin heeft zelf geen vereniging of forum opgericht dat als vehikel kon dienen om zijn boodschap te verkondigen. Wel kreeg hij steun van diverse bestaande organisaties. Tot de belangrijkste behoorden de American Zionist Council, de American Jewish Committee en vooral de US Committee for a UN Genocide Convention. Het laatste comité kwam voort uit een organisatie die streefde naar toenadering tussen christelijke en joodse denominaties. Lemkin kon de US Committee gebruiken als platform om de noodzaak van genocidebestrijding voor het voetlicht te brengen en om te lobbyen voor aanvaarding van het genocideverdrag. Via het comité kreeg hij gedaan dat 166 organisaties uit 28 landen, die tezamen meer dan tweehonderd miljoen mensen vertegenwoordigden, de Genocideconventie steunden. ${ }^{40}$ Op de lange ter-

34 Getiteld Totally unofficial man. The autobiography of Raphael Lemkin. Net zomin als zijn History of Genocide zou Lemkin dit boek voltooien. Een deel van het werk is opgenomen in Jacobs \& Totten 2002.

35 Elder 2008, p. 483.

36 Jones 2006, p. 317-318; Sunstein 1996, p. 909; Florini 1996, p. 375.

37 Zie bijvoorbeeld zijn verhandeling voor de internationale strafrechtconferentie in Madrid (Lemkin 1933).

38 Schabas 2009, p. 29.

39 Jones 2006, p. 317.

40 Elder 2008, p. 482-483. 
mijn heeft Lemkins werk geresulteerd in een netwerk van wetenschappers, overheidsfunctionarissen en activisten die zich met genocidebestrijding bezighouden en die tot op de dag van vandaag actief zijn.

Dat Lemkin erin is geslaagd de bestrijding van genocide op de politieke agenda te krijgen en te juridiseren tot op het hoogste niveau, is bijzonder. Lemkin maakte geen lange mars door de instituties. Integendeel, bij het lezen van zijn levensverhaal doemt het beeld op van een eenzame ridder die voortdurend strijd levert met de instituties. Lemkin was in alle opzichten een loner. Hij was niet getrouwd, had geen kinderen en weinig vrienden. Hij noemde zichzelf een 'habitual pessimist' die zelfs van evidente successen moeilijk kon genieten. ${ }^{41}$ Hij bewoonde een eenkamerappartement in Manhattan en werd ondanks zijn zwakke gezondheid en voortdurende geldproblemen volledig in beslag genomen door zijn missie. ${ }^{42}$ Uitgeput stierf Lemkin een voortijdige dood in 1959. Zijn begrafenis werd bijgewoond door zeven mensen. Zijn uitgebreide boekencollectie werd verdeeld over drie archieven. ${ }^{43}$

Waardoor was Lemkin in staat zijn opus magnum te voltooien? Persoonlijke factoren die daaraan zonder meer hebben bijgedragen zijn allereerst zijn intelligentie en kennis: van talen, van het recht en van het diplomatieke verkeer. Verder heeft meegespeeld dat Lemkin aanwezig was in en toegang had tot diverse netwerken. Hij was wetenschapper, had gewerkt in de rechtspraak en advocatuur, en verkeerde in kringen van politiek, bestuur en diplomatie. Ten slotte was onontbeerlijk voor het welslagen van Lemkins missie zijn ijver, volharding en enorme betrokkenheid. Deze vloeide voort uit sterk ontwikkelde ideeën over de menselijke waardigheid en, uiteraard, uit eigen ervaringen. Maar Lemkins betrokkenheid had ook een keerzijde. Inspanningen voor andere mensenrechteninitiatieven, zoals de universelemensenrechtenverklaring, ervoer hij als concurrentie. ${ }^{44}$ Lemkin ontving ook kritiek voor het feit dat hij zich minder sterk maakte voor de bescherming van politieke, sociale en economische groepen dan voor etnische en culturele minderheden. Deze houding zou volgens sommigen terug te voeren zijn op Lemkins overtuiging dat genocidebestrijding niet alleen zag op de bescherming van mensenlevens an sich, maar dat ze ook diende om de culturele 'eigenheid' van volkeren te bewaren. ${ }^{45}$ Een laatste kanttekening heeft te maken met Lemkins stijl van opereren. Uit de literatuur over Lemkin rijst het beeld op van een man die enerzijds goed aanvoelde door welke wijze van benaderen - charmant, nederig, vleiend, humoristisch, zakelijk - de kans op medewerking van zijn gesprekspartner het grootst was. Zijn kracht was tevens dat hij mensen dikwijls in hun eigen taal kon aanspreken. Bovendien verdiepte hij zich in de geschiedenis en gewoonten van een land alvorens de regering om steun te vragen. Zo informeerde hij steeds naar de juiste manier om hoogwaardigheidsbekleders aan te spreken. ${ }^{46}$

41 Jacobs \& Totten 2002, p. 397.

42 Power (2007, p. 52) beschrijft dat Lemkin 's nachts regelmatig door de straten van New York dwaalde. Hij at zodanig weinig dat hij zo nu en dan flauwviel.

43 Jacobs \& Totten 2002, p. 399.

44 Jones 2006, p. 8.

45 Bechky 2012, p. 585; Schabas 2009, p. 153-165; Jones 2006, p. 11

46 Elder 2008, p. 481-482. 
Maar paradoxaal genoeg was Lemkin anderzijds zozeer gepreoccupeerd door zijn missie dat hij mensen ook verveelde en tegen zich in het harnas joeg. Toen een sceptische journalist Lemkin eens de vraag stelde of een stuk papier een nieuwe Hitler of Stalin zou kunnen tegenhouden, reageerde hij verbolgen: 'Only man has law. Law must be built, do you understand me? You must build the law! The world is built and torn down by law!'47

Deze kanttekeningen typeren misschien Lemkins bevlogenheid, maar daarmee alleen is nog geen afdoende verklaring gegeven voor de totstandkoming van de Genocideconventie. Het waren niet alleen persoonlijke omstandigheden die daartoe hebben geleid. Zonder Holocaust zou er geen genocideverdrag zijn verwezenlijkt. In persoonlijk opzicht was de Shoah voor Lemkin een ongekende tragedie. Zoals vermeld verloor hij bijna zijn hele familie. Van de vele bloeiende joodse gemeenschappen in Europa was vrijwel niets meer over. Maar Lemkin had met de oorlog wel het tragische geluk momentum te hebben. Als een cynische speling van het lot dienden de misdaden van de nazi's als katalysator voor het proces om genocide strafbaar te stellen. Hun barbarij, die tot voor kort onvoorstelbaar leek, lag vers in het geheugen. Onder deze omstandigheden kon Lemkin politici en diplomaten gemakkelijk wijzen op de noodzaak van strafbaarstelling en preventie, als zij onwillig waren mee te werken aan zijn project.

Waarin Lemkin het verschil maakte, is dat dankzij zijn inzet een nog niet eerder gedefinieerd uitzonderlijk misdrijf bij verdrag werd erkend en strafbaar gesteld. Met de Genocideconventie, het eerste mensenrechtenverdrag van de Verenigde Naties, was een belangrijke stap gezet op weg naar voorkoming en bestraffing. Het was tevens Lemkins verdienste dat genocide niet alleen strafbaar werd verklaard in oorlogstijd, maar ook in tijden van vrede. Dat was voor sommige staten een veel hachelijker zaak, omdat ze vreesden dat het hen kon belemmeren in de bestrijding van binnenlandse opstand ('terrorisme'). Ten slotte is het bijzonder dat het internationaal belang van het voorkomen en bestraffen van genocide is erkend. Volkerenmoord is men gaan beschouwen als een misdaad tegen de mensheid als geheel, waarmee de bestrijding ervan ook een zaak voor andere staten werd. ${ }^{48}$

De Genocideconventie heeft juridische consequenties, maar in sociologisch en psychologisch opzicht is de erkenning van volkerenmoord van minstens zo grote betekenis. Genocide heeft een afschrikwekkende klank, die meer dan elk ander misdrijf huivering oproept en waardoor de roep tot ingrijpen nog sterker klinkt.

47 Power 2007, p. 51-52; Rosenthal 1988.

48 Lemkins leven en werk vertonen een aantal frappante overeenkomsten met leven en werk van een andere belangrijke rechtsgeleerde van zijn generatie met vergelijkbare ideeën en ambities: Hersch Lauterpacht. Beiden werden rond de voorlaatste eeuwwisseling in Oost-Europa geboren. Beiden waren van joodse afkomst en allebei ontvluchtten zij het antisemitisme op het Europese continent. Beide mannen ontwikkelden zich tot vooraanstaande geleerden op het terrein van internationaal recht, die gedreven werden door het verlangen de strikte soevereiniteit van staten aan banden te leggen ten gunste van de bescherming van fundamentele mensenrechten. Lauterpacht werd hoogleraar in Cambridge (Engeland) en rechter in het Internationaal Gerechtshof. Ondanks hun gelijkenissen hebben Lemkin en Lauterpacht elkaar waarschijnlijk nooit ontmoet. Voor een uitvoerige vergelijking tussen deze bondgenoten op afstand, zie Vrdoljak 2009. 
Lemkin wees ook op de grote betekenis hiervan. Toen hem werd gevraagd naar het effect van de Genocideconventie, antwoordde hij dat het succes van een wet minder van de wet zelf afhangt dan van de mensen die de wet toepassen. Met de conventie kan een sterke morele druk worden uitgeoefend. Als voorbeeld haalde Lemkin het aan de Russen gedane verwijt aan dat onder Stalin de Wolga-Duitsers, Kalmukken, Tsjertsjenzen en Tataren waren gedeporteerd. Toen de Russen in de jaren vijftig werd verweten hiermee genocide te hebben bedreven, haastte Chroestsjov zich te zeggen dat dit laster was. Enkele weken later werden de overgeblevenen van deze volken evenwel teruggebracht naar hun oorspronkelijke streken. Lemkin concludeerde: 'De conventie moet als psychologisch instrument niet worden onderschat.' 49

Een vraag die na de oorlog knaagde en die Lemkin zich (uiteraard) ook heeft gesteld, is: kwam de Genocideconventie te laat? Anders gezegd, als de conventie eerder tot stand was gekomen, zoals Lemkin had bepleit op de strafrechtconferentie in 1933, had die de Holocaust dan kunnen voorkomen? Dat is zeer onwaarschijnlijk. De wil van de nazi's tot uitroeiing van het joodse volk was zo sterk en hun moordmachine was zo dodelijk doeltreffend dat internationale strafbaarstelling hen daar niet van zou hebben weerhouden. Evenmin zou effectieve handhaving van een mensenrechtenverdrag in die jaren nauwelijks mogelijk zijn geweest, temeer daar de nazi's slechts ontvankelijk waren voor de taal van geweld. Het is ook onwaarschijnlijk dat de geallieerden door strafbaarstelling van genocide er eerder toe waren overgegaan de uitvoering van de Holocaust te belemmeren of te beëindigen. ${ }^{50}$ Wel zou het gemakkelijker kunnen zijn geweest om na de oorlog nazi's te vervolgen met een genocideverdrag in de hand, omdat het dan mogelijk was geweest hen te berechten voor misdrijven gepleegd in de jaren voorafgaand aan de oorlog. ${ }^{51}$

\section{Nalatenschap}

Inmiddels is de Genocideconventie geratificeerd door 144 landen. De meeste staten die niet aan de conventie deelnemen, zijn te vinden in Afrika, maar ook verscheidene grote landen daarbuiten (Indonesië, Japan) hebben de conventie niet geratificeerd. ${ }^{52} 144$ deelnemers is een aanzienlijk aantal, maar als bedacht wordt wat voor immens misdrijf genocide is en hoe gematigd de verplichtingen feitelijk zijn die uit de conventie voortvloeien, dan is dit aantal niet bijzonder indrukwek-

49 'Genocide, nieuwe naam voor oude misdaad', De Tijd 23 december 1957.

50 Aan kennis van de gruwelen in Oost-Europa kan het niet hebben gelegen. De geallieerden hadden reeds in 1941 sterke indicaties dat Joden en andere volken stelselmatig werden uitgeroeid, gelet op onder meer de rapporten van uit Auschwitz ontsnapte gevangenen en de Holocaust-nota die de Poolse regering in 1942 naar de geallieerden stuurde.

51 Lemkin (1947, p. 148-149) wees zelf op deze gemiste kans.

52 Japan heeft in 2007 wel verklaard de jurisdictie van het Internationaal Gerechtshof in genocidezaken te erkennen, wanneer zich een geschil voordoet met een andere staat die dezelfde verklaring heeft afgelegd. 
kend. ${ }^{53}$ Mogelijk ligt aan de aarzeling van sommige staten om toe te treden ten grondslag dat ze, zoals gezegd, in de bestrijding van binnenlandse rebellie niet gedwarsboomd willen worden door internationaalrechtelijke verplichtingen. Ook kan meespelen dat staten vrezen dat ze na toetreding verplicht zijn 'iets te doen' als ergens ter wereld volkerenmoord dreigt of werkelijkheid wordt. ${ }^{54}$ Lemkins nalatenschap laat al met al een gemengd beeld zien.

Zonder meer goed nieuws is dat het verbod op genocide al lang niet meer louter gebaseerd is op een verdrag, maar dat dit ook terug te voeren is op het internationale gewoonterecht. Dit werd voor het eerst erkend in een advies van het Internationaal Gerechtshof in 1951, waarin het hof in eloquente maar niet mis te verstane bewoordingen verklaarde dat:

'the origins of the Convention show that it was the intention of the United Nations to condemn and punish genocide as "a crime under international law" involving a denial of the right of existence of entire human groups. A denial which shocks the conscience of mankind and results in great losses to humanity, and which is contrary to moral law and to the spirit and aims of the United Nations. The ... consequence arising from this conception is that the principles underlying the Convention are principles which are recognised by civilised nations as binding on States, even without any conventional obligation.' 55

Genocide is bovendien zo apert kwaadaardig en schadelijk, zo vervolgde het Hof, dat het een schanddaad is tegen de mensheid als geheel. Als gevolg daarvan is men het genocideverbod gaan beschouwen als een regel van jus cogens, dat wil zeggen een regel van dwingend recht waar ongeacht de omstandigheden nooit van mag worden afgeweken. De verplichtingen die uit deze norm voortvloeien, zijn naar hun aard een zaak van alle landen. Alle landen hebben een juridisch belang in de bescherming van groepen mensen die met genocide worden bedreigd: het zijn verplichtingen erga omnes. ${ }^{56}$

Verheugend is verder dat de definitie van genocide in de conventie de standaard is geworden van het genocidebegrip. Ze is opgenomen in tal van nationale jurisdicties en letterlijk gedupliceerd in diverse andere bronnen van internationaal

53 Staten hoeven bijvoorbeeld niet te vrezen dat zij op grond van de Genocideconventie aansprakelijk worden gesteld voor eventueel begane wandaden voorafgaand aan toetreding tot de conventie, omdat het verdrag terugwerkende kracht mist (Schabas 2010). Zie het vervolg van deze paragraaf voor nadere juridische implicaties van het internationale genociderecht.

54 Power (2007, p. 359) verwijst naar een nota van het Amerikaanse ministerie van Defensie, geschreven na aanvang van de volkerenmoord in Rwanda in 1994: 'Be Careful. Legal at State was worried about this yesterday - Genocide finding could commit [the U.S. government] to actually "do something".'

55 Reservations to the Convention on the Prevention and Punishment of the Crime of Genocide, Advisory Opinion, ICJ Reports, 28 mei 1951, p. 12. [Cursivering is toegevoegd.]

56 Barcelona Traction, Light and Power Company Limited (Belgium v. Spain), Judgment, ICJ Reports, 5 februari 1970, par. 33-34. 
recht. ${ }^{57}$ De strikte opvatting van de genocidedefinitie heeft beperkingen, ${ }^{58}$ maar ze voorkomt ook inflatoire reflexen, die een houding van achteloosheid en inertie met zich mee kunnen brengen. Het belang van de Genocideconventie is voor een belangrijk deel gelegen in haar alarmbelfunctie. Bedroevend is echter dat als het alarm afgaat, effectief en voortvarend ingrijpen nog vaak een mijl op zeven blijkt te zijn. Denk aan Rwanda, Joegoslavië en Darfur. Door deze tragedies valt tevens te betwijfelen of de Genocideconventie daadwerkelijk afschrikwekkende werking heeft gehad.

Dat de afgelopen twintig jaar diverse internationale straftribunalen zijn opgericht, mag echter een aanzienlijke stap voorwaarts heten in de opbouw van een internationale rechtsorde. In meer of mindere mate zijn deze instituties succesvol (geweest), in die zin dat dankzij hen grove mensenrechtenschendingen, waaronder genocide, zijn erkend en bestraft.

De verplichting om genocide te voorkomen, die de Genocideconventie ook stipuleert, was daarentegen lange tijd met mist omgeven. In 2007 heeft het Internationaal Gerechtshof iets meer duidelijkheid verschaft over de inhoud en reikwijdte hiervan. Het Hof oordeelde in de Genocidezaak dat zij niet vereenzelvigd moet worden met de verplichting tot bestraffing. Ook houdt de preventieplicht niet op bij het aanmanen van de Verenigde Naties om tot actie over te gaan, maar dienen verdragstaten te doen wat binnen hun macht ligt om genocide te voorkomen, zolang hun handelen in overeenstemming is met het VN-recht. De preventieplicht strekt zich zelfs uit tot buiten de eigen landsgrenzen. De omvang van de verplichting varieert van staat tot staat en hangt volgens het Hof onder meer af van het vermogen van een land om het optreden van potentiële of daadwerkelijke genocideplegers te beïnvloeden. ${ }^{59}$ Vermeldenswaardig is in dit opzicht tevens het rechtsbeginsel Responsibility to Protect (R2P), dat de Verenigde Naties in diverse resoluties hebben omarmd. Daarin verklaarden zij dat als een land niet in staat of niet bereid is genocide of andere grove mensenrechtenschendingen te voorkomen, de verantwoordelijkheid tot effectieve bescherming van de bedreigde bur-

57 Zie artikel 4 Statuut Joegoslavië-tribunaal 1993 (ICTY); artikel 2 Statuut Rwanda-tribunaal 1994 (ICTR); artikel 17 Draft Code of Crimes against the Peace and Security of Mankind; artikel 6 Statuut Internationaal Strafhof 1998 (ICC).

58 Zo levert de specifieke intentie om een minderheid als zodanig te vernietigen of onderdrukken, die bewezen moet worden om van genocide te spreken, een zware bewijslast op. Ook beperkt de bescherming van de conventie zich, als gezegd, tot nationale, etnische, religieuze en raciale groepen.

59 Application of the Convention on the Prevention and Punishment of the Crime of Genocide (Bosnia and Herzegovina v. Serbia and Montenegro), Judgment, ICJ Reports, 26 februari 2007, par. 427, 430. Overigens biedt het VN-Handvest in hoofdstuk VII een grondslag voor gewapend ingrijpen, waartoe de Veiligheidsraad kan beslissen in geval van een bedreiging van de internationale vrede en veiligheid. Wanneer genocide dreigt of werkelijkheid wordt, neemt de Veiligheidsraad blijkens zijn resoluties snel aan dat daar sprake van is, ook in binnenlandse situaties (UN Security Council Resolution 940, 31 juli 1994, UN Doc. S/res/940). 
Reyer Baas

gerbevolking verschuift naar de internationale gemeenschap. ${ }^{60}$ In uiterste omstandigheden kan daarbij militair worden ingegrepen. ${ }^{61}$

Nog al te vaak blijft het echter bij woorden. Met enige voorzichtigheid valt dan ook te concluderen dat de Genocideconventie er tot dusver niet werkelijk in heeft geresulteerd dat volkerenmoord wordt voorkomen, maar wel dat ze eerder tot bestraffing heeft geleid. Wellicht zal consequente berechting van de hoofdverantwoordelijken voor zware mensenrechtenschendingen - door internationale tribunalen of in de nationale strafrechtspleging - er in de toekomst toe leiden dat er indirect van de conventie toch preventieve werking uitgaat.

Bovenal blijkt uit de geschetste ontwikkelingen dat het pantser van staatssoevereiniteit niet meer zo hard is dat aansprakelijkheid voor grove mensenrechtenschendingen er zonder meer op afketst. Integendeel, de bescherming van universele mensenrechten is een steeds prominentere rol in het internationale recht gaan innemen. En daaraan heeft Raphael Lemkin indrukwekkend bijgedragen.

\section{Literatuur}

Bechky, P.S., 'Lemkin's situation. Toward a rhetorical understanding of genocide', Brooklyn Law Review 2012, vol. 77(2), p. 551-624.

Cooper, J., Raphael Lemkin and the Struggle for the Genocide Convention, Basingstoke/New York: Palgrave Macmillan 2008.

Elder, T., 'What you see before your eyes: documenting Raphael Lemkin's life by exploring his archival papers, 1900-1959', Journal of Genocide Research 2005, vol. 7 (4), p. 469-499.

Florini, A., 'The Evolution of International Norms', International Studies Quarterly 1996, vol. 40 (3), p. 363-389.

Jacobs, S.L. \& S. Totten, 'Totally Unofficial Man. Raphael Lemkin', in: S.L. Jacobs \& S. Totten (eds.), Pioneers of Genocide Studies, New Brunswick: Transaction Publishers 2002, p. 365-400.

Jones, S., Genocide. A comprehensive introduction, London/New York: Routledge 2006.

LeBlanc, J.L., The United States and the Genocide Convention, Durham/London: Duke University Press 1991.

Lemkin, R., 'Les Actes constituant un danger général (interétatique) considérés comme délits de droit de gens. Rapport special présenté à la V-me Conférence pour l’Unification du Droit Pénal à Madrid (14-20 Septembre 1933).'

Lemkin, R., Axis rule in occupied Europe. Laws of occupation, analysis of government, proposals for redress, Washington DC: Carnegie Endowment for International Peace 1944.

60 World Summit, Outcome Document, 2005, par. 138-139; UN General Assembly Resolution, 24 oktober 2005, UN Doc. A/res/60/1; UN Security Council Resolution 1674, 28 april 2006, UN Doc. S/res/1674.

61 In twee recente resoluties van de VN Veiligheidsraad is verwezen naar de verantwoordelijkheid tot bescherming. Het betreft resolutie 1973 (17 maart 2011, UN Doc. S/res/1973) en resolutie 2085 (20 december 2012, UN Doc. S/res/2085), die de juridische basis verschaften voor militair ingrijpen in Libië respectievelijk in Mali. Ook het Internationaal Gerechtshof heeft zich door het beginsel laten beïnvloeden, getuige zijn uitspraak in: Application of the Convention on the Prevention and Punishment of the Crime of Genocide (Bosnia and Herzegovina v. Serbia and Montenegro), Judgment, ICJ Reports, 26 februari 2007, par. 166, 427, 430. 
Lemkin, R., 'Genocide', American Scholar 1946, vol. 15 (2), p. 227-230.

Lemkin, R., 'Genocide as a Crime under International Law', American Journal of International Law 1947, vol. 41 (1), p. 145-151.

Power, S., 'A problem from hell': America and the age of genocide, New York: Harper Perennial 2007.

Rosenthal, A.M., 'On my mind; a man called Lemkin', New York Times 18 October 1988, p. A31.

Schabas, W., Genocide in international law. The crime of crimes, Cambridge: Cambridge University Press 2009.

Schabas, W., 'Retroactive Application of the Genocide Convention', University of St. Thomas Journal of Law \& Public Policy 2010, vol. 4 (2), p. 36-59.

Sunstein, C.R., 'Social Norms and Social Roles', Columbia Law Review 1996, vol. 96 (4), p. 903-968.

Vrdoljak, A.F., 'Human Rights and Genocide: the Work of Lauterpacht and Lemkin in Modern International Law', European Journal of International Law 2009, vol. 20 (4), p. 1163-1194.

Wald, P.M., 'Genocide and Crimes Against Humanity', Washington University Global Studies Law Review 2007, vol. 6, p. 621-633. 